\title{
Effect of Li-Ferrite on the Temperature Sensitivity of Polycrystalline Li-Zn-Cu Ferrite
}

\author{
M. Naoe, T. Omura, M. Oishi, S. Okazaki, T. Sato, K. Yamasawa, and Y. Miura \\ Spin Device Technology Center, Shinshu University, 4-17-1, Wakasato, Nagano 380-8553, Japan
}

\begin{abstract}
$\mathrm{Mn}$-substituted $\mathrm{Li}-\mathrm{Zn}-\mathrm{Cu}$ ferrite polycrystal is known to be a high-frequency ferrite. The authors recently clarified that this ferrite exhibits strong temperature-dependent magnetic properties. To our knowledge, detailed information on the temperature dependence of this new temperature-sensitive ferrite has not been reported. In the present study, several polycrystalline ferrites were fabricated while controlling the Li-ferrite content to investigate the chemical composition dependence of the temperature characteristics of their magnetic properties. As a result, it was clarified that the strong temperature sensitivity of the $\mathrm{Li}-\mathrm{Zn}-\mathrm{Cu}$ ferrite depended on the large temperature coefficient of the anisotropy constant of Li-ferrite. In addition, the smaller Li-ferrite content intensified the temperature dependence of the apparent anisotropy field, hence reinforcing the temperature-dependent magnetic properties.
\end{abstract}

Key words: temperature-sensitive ferrite, polycrystalline $\mathrm{Li}-\mathrm{Zn}-\mathrm{Cu}$ ferrite, Li-ferrite, complex permeability, magnetization, anisotropy constant, apparent anisotropy field

\section{多結晶 $\mathrm{Li}-\mathrm{Zn}-\mathrm{Cu}$ フェライトの感温性に及ぼす $\mathrm{Li}$ フェライトの影響}

直江正幸 - 大村智昭 - 生石正之 ・岡崎眞也 - 佐藤敏郎 - 山沢清人 - 三浦義正 信州大学スピンデバイステクノロジーセンター, 長野市若里 4-17-1（テ380-8553）

\section{1.はじめに}

これまでの研究で，筆者らは，高周波フェライトである多結晶 $\mathrm{Li}-\mathrm{Zn}-\mathrm{Cu}$ フェライト 1)の透磁率に強い 温度依存性があることを見 いだし，このフェライトを磁芯とすることで $L C$ 共振型温度セン サ2)を集積化および小型化する基礎検討を行ってきた 3 .

多結晶フェライトの感温性は, フェライト組成と微細構造によ って大きく変動すると考えられる ${ }^{4-8)}$. 高周波フェライトでありな がら感温性を有するといら新しい感温フェライトである $\mathrm{Li}-\mathrm{Zn}-\mathrm{Cu}$ フェライトの感温性は, 上記の温度センサ開発のためのみならず, 材料科学の観点でも興味深い課題であるが，これが詳細に考察さ れた報告は，調べた限り見受けられない。

本論文では, この課題を明らかにしてゆく一環として, $\mathrm{Li}-\mathrm{Zn}-\mathrm{Cu}$ フェライトの感温性とフェライト組成との関係における Li フェラ イトの影響を調べた結果を述べる. はじめに, $\mathrm{Li}-\mathrm{Zn}-\mathrm{Cu}$ フェライ トの磁気特性の強い温度依存性は, 構成成分である Li フェライト にあると考え, $\mathrm{Li}$ フェライトまたは $\mathrm{Ni}$ フェライトと $\mathrm{Zn}$ フェライ トとの比率, か $\mathrm{Cu}$ フェライト固溶量が同じである $\mathrm{Li}-\mathrm{Zn}-\mathrm{Cu}$ フ ェライトおよび $\mathrm{Ni}-\mathrm{Zn}-\mathrm{Cu}$ フェライト多結晶体の感温性を比較す ることで，仮説を検証した，次に，焼結密度は同じでありながら $\mathrm{Li}$ フェライト固溶量が異なるいくつかの試料を作製し，これらの 磁気特性の温度依存性変化について調べ，詳細に考察した。

\section{Li-Zn-Cu フェライトの感温性に及ぼす Li フェライトの特性}

\section{1 実験方法}

$\mathrm{Li}$ フェライトまたは $\mathrm{Ni}$ フェライトと $\mathrm{Zn}$ フェライトとの比がお おむね $3: 1, \mathrm{Cu}$ フェライト固溶量が $20 \mathrm{~mol} \%$ となるよう, フェ ライトの組成を $\mathrm{Li}_{0.3} \mathrm{Zn}_{0.2} \mathrm{Cu}_{0.2}\left(\mathrm{Fe}_{0.9} \mathrm{Mn}_{0.1}\right)_{2.3} \mathrm{O}_{4}$, ならびに $\mathrm{Ni}_{0.617} \mathrm{Zn}_{0.183} \mathrm{Cu}_{0.2} \mathrm{Fe}_{2} \mathrm{O}_{4}$ とした. $\mathrm{Li}-\mathrm{Zn}-\mathrm{Cu}$ フェライトにおいて, 比抵抗を高めるために Fe を $10 \mathrm{~mol} \%$ の $\mathrm{Mn}$ で置換している以外
は, ほぼ同じ組成である. $\mathrm{Li}_{2} \mathrm{CO}_{3}, \mathrm{ZnO}, \mathrm{CuO}, \mathrm{Fe}_{2} \mathrm{O}_{3}, \mathrm{Mn}_{3} \mathrm{O}_{4}$, および $\mathrm{NiO}$ の高純度微粉末を前記の組成になるように精密に科量 した. 工程中で $\mathrm{Fe}$ 過剩組成にならないように, $\mathrm{Fe}_{2} \mathrm{O}_{3}$ は予め 1〜 $2 \mathrm{~mol} \%$ 分減量してある. これらの原料を, $\mathrm{Li}-\mathrm{Zn}-\mathrm{Cu}$ フェライトで は乾式混合機を用いて 1 時間混合, $\mathrm{Ni}-\mathrm{Zn}-\mathrm{Cu}$ フェライトでは湿式 ボールミルで 24 時間混合後, 電気炉で大気中 $800^{\circ} \mathrm{C} \cdot 3$ 時間の仮 焼成を行った. 仮焼成粉は, 湿式鉄球ボールミルを用いて粉砕し, 平均粒子径約 $1.1 \mu \mathrm{m}$ のフェライト粉末を得た. 少量のバインダを 加え, フェライト粉末を造粒し, $98 \mathrm{MPa}$ の圧力で一軸プレス成形 したリング状もしくはペレット状の成形体を得た. 室温の磁化特 性が同等となるように, $\mathrm{Li}-\mathrm{Zn}-\mathrm{Cu}$ フェライトは $912^{\circ} \mathrm{C}, \mathrm{Ni}-\mathrm{Zn}-\mathrm{Cu}$

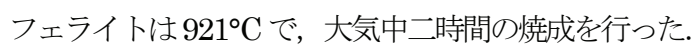

得られた多結晶体の複素透磁率スペクトル $(10 \mathrm{MHz} \sim 1 \mathrm{GHz})$ お よびその温度依存性 $\left(-35 \sim 125^{\circ} \mathrm{C}\right)$ は, インピーダンスアナライザ (4291A, Hewlett Packard)および恒温槽(SU-240, タバイエスペ ック)を組み合わせて測定した。 また，振動試料型磁力計(BHV-55, 理研電子)および付属の温度特性測定装置(VSM-VT900)を用いて, 各温度(室温〜 $520^{\circ} \mathrm{C}$ )での飽和磁化曲線を得た.

\section{2 実験結果と考察}

Fig. 1 に，それぞれの測定温度における多結晶 $\mathrm{Li}-\mathrm{Zn}-\mathrm{Cu}$ フェラ イト, および $\mathrm{Ni}-\mathrm{Zn}-\mathrm{Cu}$ フェライトの複素透磁率の周波数特性を示 す. $\mathrm{Li}-\mathrm{Zn}-\mathrm{Cu}$ フェライトは, $\mathrm{Ni}-\mathrm{Zn}-\mathrm{Cu}$ フェライトと比較すると, 明らかに大きな複素透磁率の正の温度依存性を有していることが わかる. 定量的に検討するために，それぞれ $10 \mathrm{MHz}$ での実数部 $\mu^{\prime}$ の温度依存性を, Fig. 2 にプロットした. 室温での透磁率の大き さはほぼ同じであるが, -35 から $125^{\circ} \mathrm{C}$ までの温度変化に対し， $\mathrm{Li}-\mathrm{Zn}-\mathrm{Cu}$ フェライトの透磁率は, 約 1.89 倍になった. 一方, $\mathrm{Ni}-\mathrm{Zn}-\mathrm{Cu}$ フェライトでは約 1.10 倍であった.

次に, Fig. 3 , 両多結晶フェライトの飽和磁化の温度依存性を 


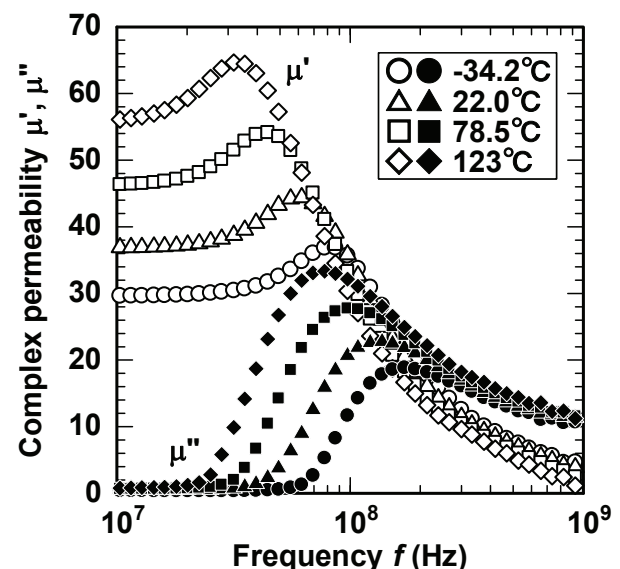

$\begin{array}{ll}\text { (a) } \mathrm{Li} 0.3 \mathrm{Zn}_{0.2} \mathrm{Cu}_{0.2}\left(\mathrm{Fe}{ }_{0.9} \mathrm{Mn}_{0.1}\right)_{2.3} \mathrm{O}_{4} & \text { (b) } \mathrm{Ni} 0.617 \mathrm{Zn} 0.183 \mathrm{Cu}_{0.2} \mathrm{Fe}_{2} \mathrm{O}_{4} \\ \text { Fig. } 1 & \text { Complex permeability spectra of polycrystalline ferrites at various ambient temperature }\end{array}$

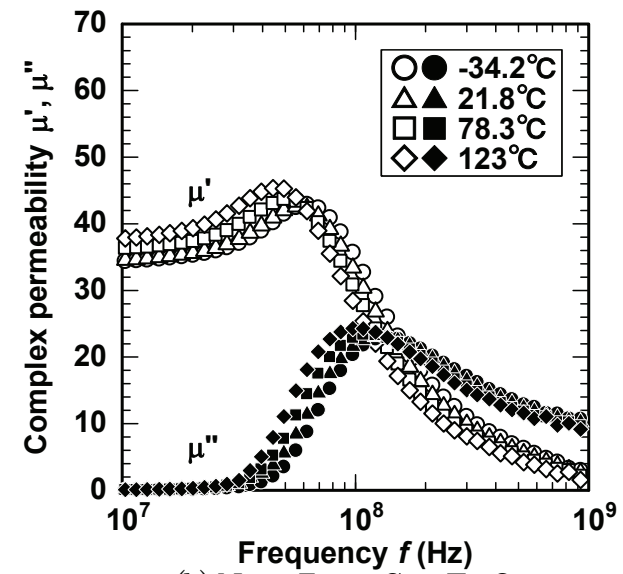

(b) $\mathrm{Ni}_{0.617} \mathrm{Zn} 0.183 \mathrm{Cu}_{0.2} \mathrm{Fe}_{2} \mathrm{O}_{4}$
various ambient temperatures.

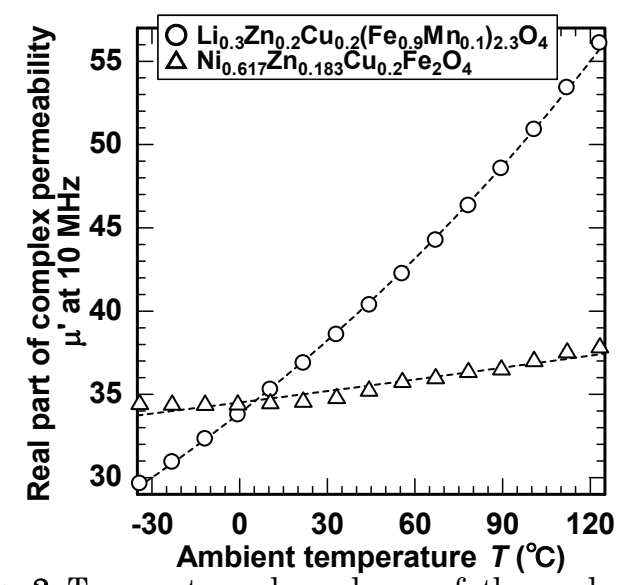

Fig. 2 Temperature dependence of the real part of the complex permeability at $10 \mathrm{MHz}$ in each ferrite.

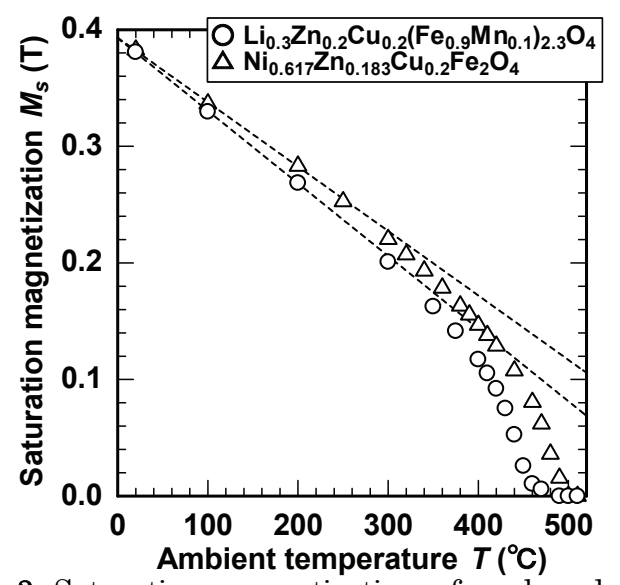

Fig. 3 Saturation magnetization of each polycrystalline ferrite as a function of the ambient temperature.

示した. $\mathrm{Li}-\mathrm{Cr}$ 系フェライト 9,10)のような特殊な組成は除き, $\mathrm{Li}$ 系 およびNi系フェライトの磁化の温度依存性は共にR型を示すこと が知られているので 11), より低温の領域では磁化の温度依存性が 非線形になると考えられるが，本研究の測定温度範囲ではキュリ 一点直近を除き，ほほ線形変化と見な寸ことができる．よって， 室温の值からの漸近線を引き，その傾きで磁化の温度依存性の強 弱を判断した，その結果，室温における飽和磁化がほぼ同じであ る両者の飽和磁化の温度依存性には透磁率ほどの大きな差は見ら
れないことがわかった. なお, $\mathrm{Li}-\mathrm{Zn}-\mathrm{Cu}$ フェライトのキュリー点 が若干低いのは, 磁気モーメントが $\mathrm{Fe}^{3+}\left(5 \mu_{\mathrm{B}}\right)$ よりも小さい $\mathrm{Mn}^{3+}(4 \mu \mathrm{B})$ の導入により, スピネルの A-B 副格子間の超交換相互 作用が弱くなるからである.

微細構造が異なると，磁壁移動の容易さが変化する，つまり， 結晶粒径が大きければ磁壁は動きや寸く, 磁壁ピンニングの要因 となる結晶粒界が多ければ移動が妨げられ, 焼結密度が小さけれ ばギャップコアと同じく閉気孔により感温性は弱まる. 仮にフェ ライト組成が同じでも, 微細構造が異なると磁壁移動の温度依存 性に差が現れ，透磁率の温度依存性が変化すると考えられる，そ こで, 測定に用いた試料の破断面を, 走查電子顕微鏡を用いて観 察したが, $\mathrm{Ni}-\mathrm{Zn}-\mathrm{Cu}$ フェライトの方が小さい結晶粒が若干多い以 外に顕著な差は見られなかった。相対焼結密度にも有意差はほと んどなかった. よって，この程度の結晶粒径・密度の差で Fig. 2 のような透磁率の温度依存性の劇的な差が生ずるとは考えにくい. 次に, 透磁率 $\mu$ を磁気異方性定数で表現すると, 下式(1)のよう になる ${ }^{12)}$.

$$
\mu \propto M_{s} / \sqrt{K}
$$

この式によれば, $\mu$ の温度による变化は, 磁気異方性定数 $K$ と磁 化 $M_{S}$ の温度依存性に関係することとなる. Fig. 3 にも示されたよ うに, 磁化は温度上昇に対して低下寸るが，透磁率が正の温度依 存性を示すということは， $M_{S}$ が 0 に近づくよりも，Kがそれ以上 に急激に 0 に近づくことに起因している. 両者の飽和磁化の温度 依存性に劇的な差はないのだから， $\mathrm{Ni}-\mathrm{Zn}-\mathrm{Cu}$ フェライトよりも $\mathrm{Li}-\mathrm{Zn}-\mathrm{Cu}$ フェライトの磁気異方性定数の温度係数が大きいことが, 透磁率の温度依存性の差として現れていると考えられる.

両者の三元フェライト組成における構成成分では, Zn フェライ トおよび $\mathrm{Cu}$ フェライトは同じで, $\mathrm{Li}$ フェライトか $\mathrm{Ni}$ フェライト かが異なる. そこで, この二つの単元フェライトの磁気異方性定 数の温度依存性を調べ, 温度係数を見積もった. その結果, $\mathrm{Li}$ フ エライトは約 $32 \mathrm{~J} \cdot \mathrm{m}^{-3} /{ }^{\circ} \mathrm{C}$ に対し, $\mathrm{Ni}$ フェライトは約 $7 \mathrm{~J} \cdot \mathrm{m}^{-3} /{ }^{\circ} \mathrm{C}$ であることがわかった 13,14). よって, 続報として別途詳細に報告 する予定である $\mathrm{Fe} の \mathrm{Mn}$ 置換の影響を考慮しても， $\mathrm{Li}-\mathrm{Zn}-\mathrm{Cu}$ フ ェライトの温度依存性の根源は, $\mathrm{Li}$ フェライトの磁気異方性定数 の温度係数の大きさに起因するところが大きいと言える. 
以上のように, 多結晶 $\mathrm{Li}-\mathrm{Zn}-\mathrm{Cu}$ フェライトの感温性の根源とし て $\mathrm{Li}$ フェライトの磁気異方性の温度依存性を取り上げ，この影響 度を明らかにした. 次に, この Li フェライトの固溶量が異なると， $\mathrm{Li}-\mathrm{Zn}-\mathrm{Cu}$ フェライト多結晶体の感温性がどのように変化するのか を検討した結果を記す。

\section{Li フェライト固溶量の影響}

\section{1 実験方法}

多結晶フェライトの作製および評価の方法は前節と同じである が，ここでは，フェライト組成の影響を調べるために， (1-z) $\left[\mathrm{Li0}_{0.5 \mathrm{x}} \mathrm{Zn}_{1-x}\left(\mathrm{Fe}_{1-y} \mathrm{Mn}_{y}\right)_{2+0.5 \mathrm{x}} \mathrm{O}_{4}\right]+{ }_{2 \mathrm{Cu}} \mathrm{C}\left(\mathrm{Fe}_{1-y} \mathrm{Mn}_{y}\right)_{2} \mathrm{O}_{4}$ の化学式に おいて, Li- $\mathrm{Zn}$ フェライト成分における Li フェライトの固溶割合 を意味する化学組成 $x, \mathrm{Fe}$ の Mn 置換割合を表寸化学組成 $y$, そ して $\mathrm{Cu}$ フェライト固溶割合である化学組成 $z$ を，それぞれ $0.15 \leqq x \leqq 0.85$ ( 0.10 毎)， $y=0.05$ ，および $z=0.40$ となるように 原料を精密科量した. 加えて, 試料の焼結密度の差による磁性体 の体積占有率の影響の差を無視できるように，焼成温度を約 880 から $900^{\circ} \mathrm{C}$ まで変化させることで, 試料の相刘焼結密度を揃えた.

\section{2 実験結果と考察}

Fig. 4 は, 各試料の静的透磁率 $\mu$ の温度依存性の変化を示して いる. ここでの静的透磁率とは, 複素透磁率の周波数特性におい

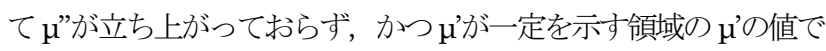
ある. 室温での静的透磁率は, 他の組成系でもよく知られている ように ${ }^{15)}$, 化学組成 $x$ の減少(Zn フェライトの増加もしくは Li フ ェライトの減少に伴い大きくなった. これは, $\mathrm{Ni}-\mathrm{Zn}$ フェライト の例で知られる, スピネルフェライトの Snoek の限界則 16)に従う ものである. また，これに伴い温度依存性も強くなっていること がわかった. そこで, 室温(約 $22^{\circ} \mathrm{C}$ )での值を基準として規格化し た結果を, Fig. 5 に示した. アルキメデス法で測定した各試料の相 対焼結密度は約 $95 \%$ でほぼ一定であったが, 化学組成 $x$ の減少に より, 透磁率の温度依存性はほぼ一定の割合で強くなっているこ とが定量的にも理解できる. ちなみに，両図に破線で示してある ものは, 最小二乗法による指数関数の近似線である. これらの近 似線はすべて 0.999 の相関係数を有していたので，この系の温度 依存性は単純な指数関数で表現することができ 3$)$, 化学組成 $x$ が変 化してもその傾向は保たれるということである.

全ての試料で測定温度範囲が同じであるので，単にこの範囲と Hopkinson 効果を伴うキュリー点との温度的位置関係が化学組成 $x$ の増減に伴って変化することにより, キュリ一点近傍の透磁率急 変領域を見ているのか否かの違いによるもののように見えるが， 定量的および工学的には不十分な見解である.

ここで，磁化など透磁率以外の特性の温度依存性についても， 同様にフェライト組成による変化が見られると考え, この系の飽 和磁化 $M_{S}$ の温度依存性を測定した結果を Fig. 6 に示す. 化学組成 $x$ の減少に伴い, キュリー点が低下した. これも, $\mathrm{Ni}-\mathrm{Zn}$ 系フェラ イトなどの一般的なスピネルフェライトにも見られる現象である 17)。また, 室温の飽和磁化は変化しているが 18), キュリー点の低 下と共に, 磁化の温度依存性も強くなっていることが見て取れた. そこで, 透磁率と同様に, 室温(約 $20^{\circ} \mathrm{C}$ )の值を基準として規格化 した結果を Fig. 7 に示した. 漸近線の傾きを用いて飽和磁化の温

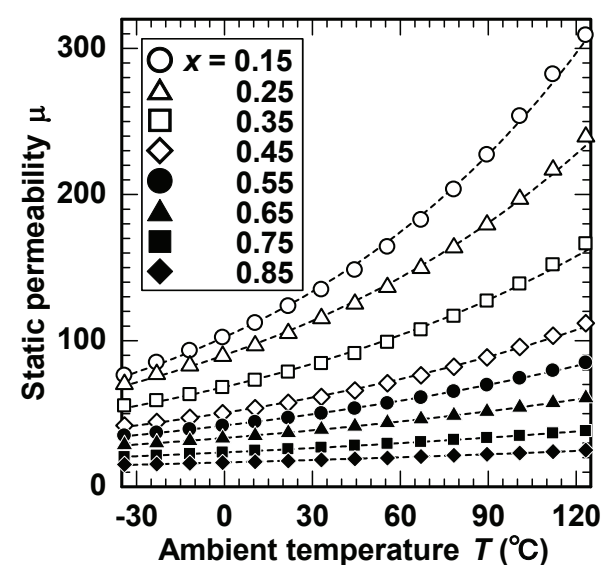

Fig. 4 Temperature dependence of the static permeability in each chemical composition $x$ for the Li-ferrite content of $\left(\mathrm{Li}_{0.5 \times} \mathrm{Zn}_{1-x}\right)_{0.6} \mathrm{Cu}_{0.4}\left(\mathrm{Fe}_{0.95} \mathrm{Mn}_{0.05}\right)_{2+0.3 x} \mathrm{O}_{4}$ polycrystal $(0.15 \leqq x \leqq 0.85)$. Broken lines denote the approximate lines of exponential functions.

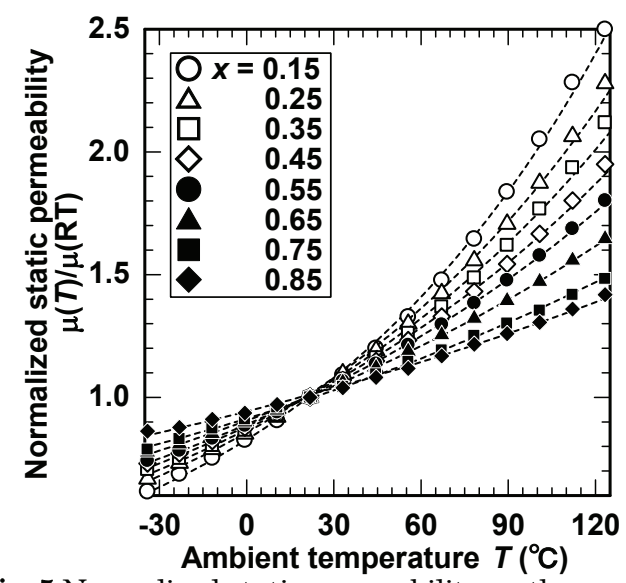

Fig. 5 Normalized static permeability on the y-axis of Fig. 4.

度依存性の強弱を評価すると, 透磁率と同様に, 化学組成 $x$ の減 少により強くなっていることが理解できる.

ここで, Fig. 4 およびFig. 6 において, それぞれの近似線( $\ln \mu$ $=\mathrm{a} T+\mathrm{b})$ および漸近線 $\left(M_{S}=-\mathrm{c} T+\mathrm{d}\right)$ の傾きの絶対值 $|\mathrm{a}|$ および $|-c|$ を, それぞれの温度係数 $d \mu / d T$ および $d M d d T$ と定義する. $d \mu l d T$ および $d M d d T$ の化学組成 $x$ 依存性は, Fig. 8 で示される. いずれも, 化学組成 $x$ とは線形の依存性として近似できることが わかる. つまり,$d \mu / d T$ および $d M_{d} d T$ をそれぞれ縦軸・横軸にし てプロットするならば, 正の傾きを持つ線形の関係になるという ことである. これは, 多結晶 $\mathrm{Li}-\mathrm{Zn}-\mathrm{Cu}$ フェライトでは, 飽和磁化 の温度係数が大きいほど透磁率のそれも大きくなることを表し, 飽和磁化の温度依存性が，透磁率のそれを判断する目安になるこ とを指し示す結果である.

ただし, 式(1)によれば, 化学組成 $x$ の増加に伴って飽和磁化の 温度依存性のみが強くなってゆくならば, 透磁率の温度依存性は 弱くなるはずである. 加えて, $\mathrm{Mn}-\mathrm{Zn}$ フェライトのような従来の 感温フェライトでも確認されているように, キュリー点が低く, それゆえ高透磁率であるスピネルフェライトであるほじ, Hopkinson 効果による透磁率の急変が顕著になる ${ }^{19)}$.つまり, $\mathrm{Li}$ フェライト固溶量と透磁率の温度依存性との関係を決定するのも, 先に述べたように磁気異方性の温度依存性に起因していると予測 
され, 磁気異方性の温度係数が化学組成 $x$ の増減に伴って減増す ることに対応すると考えられる.

$\mathrm{Li}-\mathrm{Zn}$ または $\mathrm{Li}-\mathrm{Zn}-\mathrm{Cu}$ フェライトの磁気異方性定数の温度依存 性を直接示寸文献は調べた限り見つからないが, Li-Zn フェライト における室温での異方性定数の $\mathrm{Li}$ フェライト固溶量依存性の文献 值 ${ }^{19)}$ と, $\mathrm{Fe}$ 過剩でない $\mathrm{Ni}-\mathrm{Zn}$ フェライトにおける異方性の $\mathrm{Ni}$ フ エライト量変化に伴う温度係数の変化 ${ }^{13)}$ から推測すると, 本研究

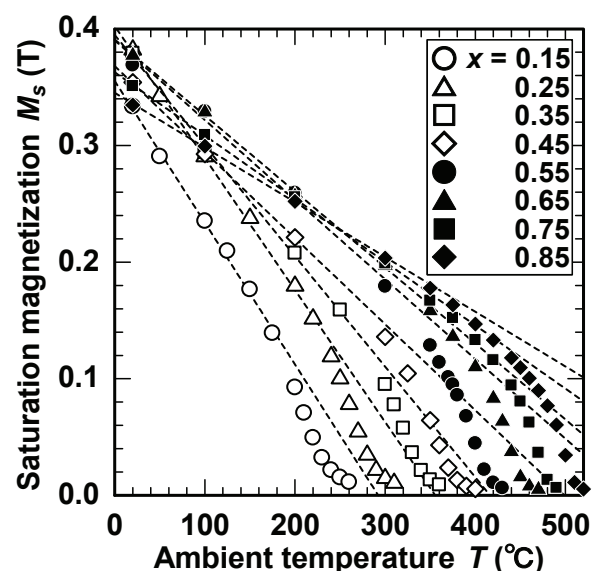

Fig. 6 Relationship between the temperature-dependent saturation magnetization and chemical composition $x$ in $\left(\mathrm{Li}_{0.5 x} \mathrm{Zn}_{1-x}\right)_{0.6} \mathrm{Cu}_{0.4}\left(\mathrm{Fe}_{0.95} \mathrm{Mn}_{0.05}\right)_{2+0.3 x} \mathrm{O}_{4}$ polycrystal $(0.15 \leqq x \leqq 0.85)$

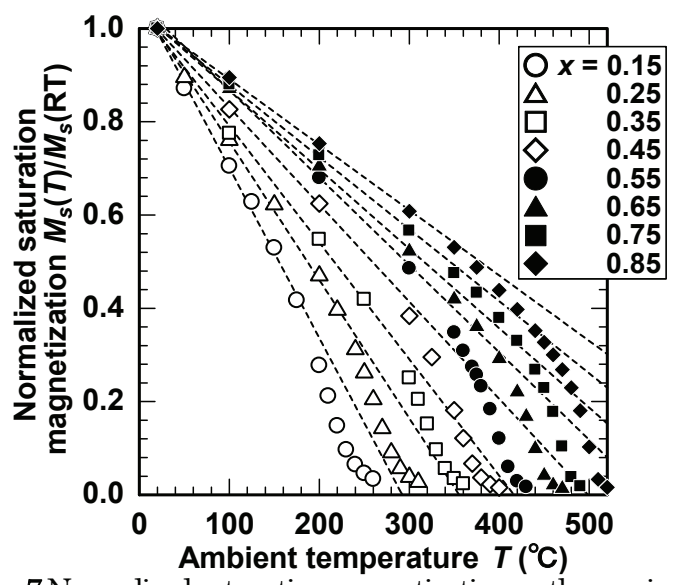

Fig. 7 Normalized saturation magnetization on the y-axis of Fig. 6.

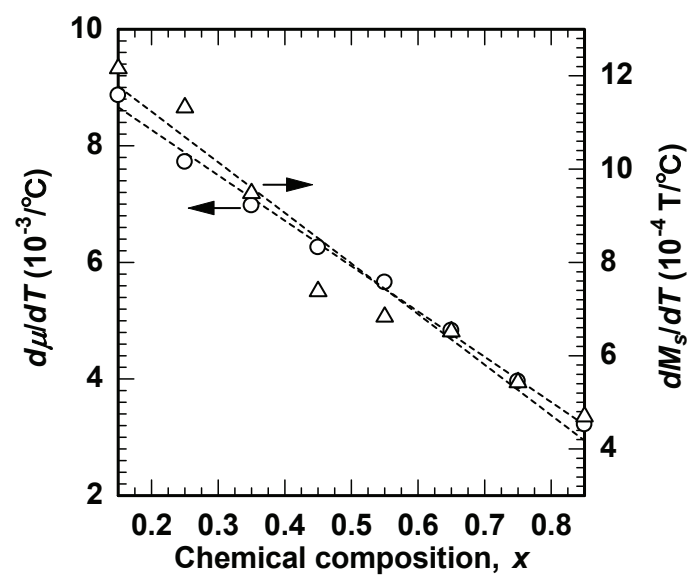

Fig. 8 Chemical composition $x$ vs. temperature coefficient of the permeability $d \mu / d T(\bigcirc)$, and saturation magnetization $d M_{\triangleleft} d T(\triangle)$, respectively.
での $\mathrm{Li}-\mathrm{Zn}-\mathrm{Cu}$ フェライト試料においても化学組成 $x$ が減少するほ ど異方性定数の絶対值は減少するが，温度依存性はむしろ強くな ると考えられる. その結果として, 化学組成 $x$ の減少に伴って透 磁率の温度依存性が強くなったことが示唆される.

この仮説を確認するためには, 異方性磁界の温度係数と透磁率 のそれとの相関性を評価すればよい. しかし, 正確な異方性磁界 は, 単結晶の困難軸厉磁における飽和磁化曲線から見積もられな ければならないが，多結晶体は微結晶がランダムに集合したもの であるので, 容易軸/困難軸を明確に区別することは不可能である. よって, 多結晶フェライトの磁気異方性の傾向を知る目安として 平塚らが提唱している見掛けの異方性磁界 21), およびその温度依 存性を評価のパラメータとして導入した. Fig. 9 に示したような第 一象限での飽和磁化曲線の一例を用いれば，この磁化曲線に従う 斜線と飽和磁化に従う水平線との交点における磁界の強さを, 見 掛けの異方性磁界とする. それぞれの試料の各温度での飽和磁化 曲線から見掛けの異方性磁界を読みとり, その温度依存性を見積 もった. これにより, 温度依存性における各試料固有の磁気異方 性定数と透磁率との相関性を間接的に評価できると考えられる. この記号表記は, 異方性磁界 $H_{a}$ と区別するために $H_{a}$ とした.

Fig. 10 に, 見掛けの異方性磁界の温度依存性が, 化学組成 $x$ に 対応して変化する様子を示した. 図のように, 見掛けの異方性磁 界の温度依存性は, 飽和磁化に類似した変化を示した. 具体的に

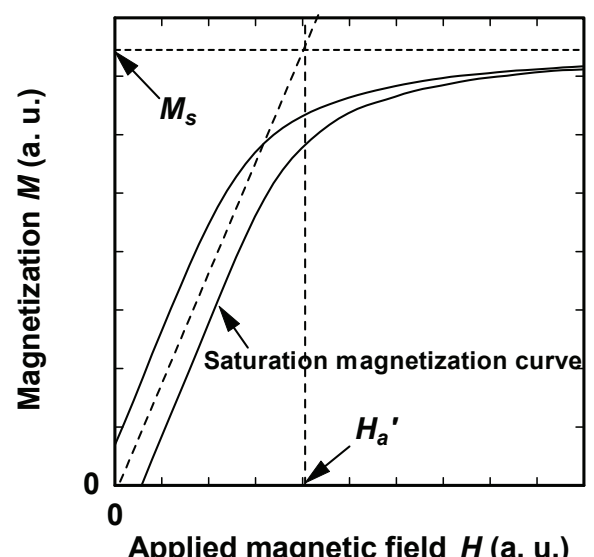

Fig. 9 Principle for estimating the anisotropy field $H_{a}$.

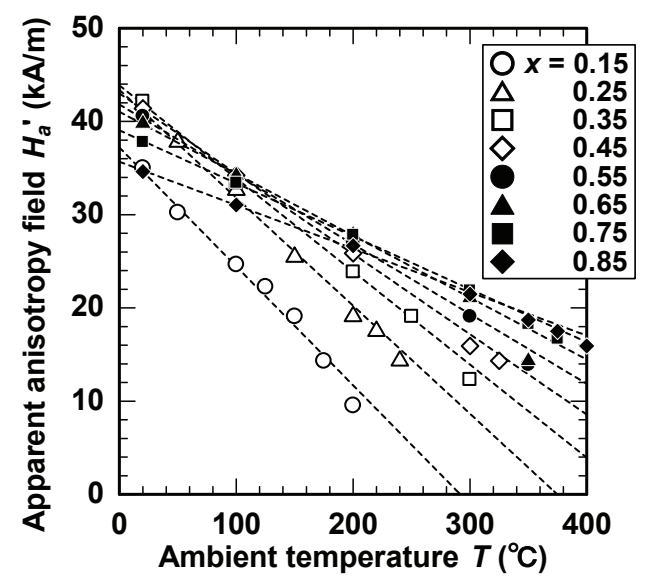

Fig. 10 Temperature dependence of the apparent anisotropy field $H_{a}$ in $\left(\mathrm{Li}_{0.5 x} \mathrm{Zn}_{1-x}\right)_{0.6} \mathrm{Cu}_{0.4}\left(\mathrm{Fe}_{0.95} \mathrm{Mn}_{0.05}\right)_{2+0.3 x} \mathrm{O}_{4}$ $(0.15 \leqq x \leqq 0.85)$. 
は，この温度領域において，キュリー点近傍で急激に減少するま では漸近線に則る線形の温度依存性を有し，化学組成 $x$ の減少に 伴って漸近線の傾きが増加した. そこで, ここでも漸近線の傾き の絶対值を, 異方性磁界の温度係数 $d H_{a}^{\prime} / d T$ と定義し, その化学 組成 $x$ 依存性を調べた結果を Fig. 11 に示す. 化学組成 $x$ が増加す ると, $d H_{a}^{\prime} l d T$ はリニアに減少することがわかった.つまり, $d \mu l d T$ も化学組成 $x$ と負の傾きを持つ線形の相関関係にあるのだから, $d H_{a}^{\prime} / d T$ と $d \mu l d T$ には線形の相関関係があることが容易に予測さ れる. この関係を示したものが Fig. 12 であり, 線形の関係を示す ことが確認できる. $d H_{a}^{\prime} / d T$, 磁気異方性の温度依存性に対応す るので, 透磁率の温度依存性が化学組成 $x$ の減少に伴って強くな るのは, 磁気異方性の温度依存性が強くなるためであると結論づ けられる結果である. 加えて, $\mathrm{Li}-\mathrm{Zn}-\mathrm{Cu}$ フェライトを感温デバイ スに適用してゆく場合に，Li フェライトの固溶量を制御すること によって, 一義的にデバイス特性(感温インダクタンス)を制御でき ることが明らかになったと言える.

\section{4. まとめ}

今回, 高周波フェライトでありながら強い感温性を示寸多結晶 $\mathrm{Li}-\mathrm{Zn}-\mathrm{Cu}$ フェライトの温度特性を詳細に調査するため, 構成成分 である $\mathrm{Li}$ フェライトが与える影響について検討した.

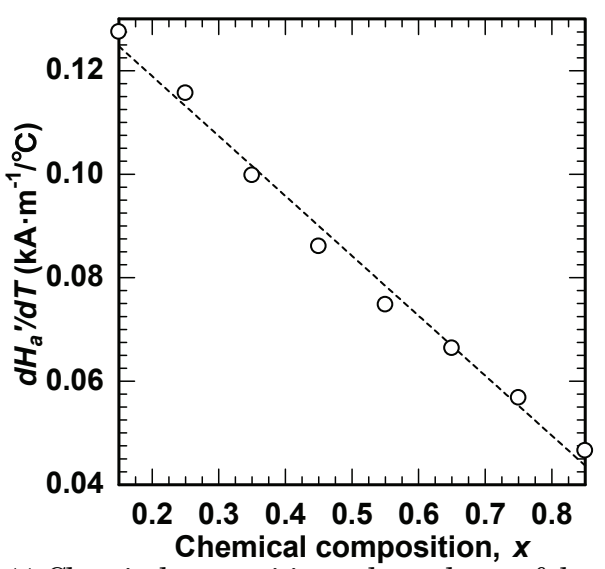

Fig. 11 Chemical composition $x$ dependence of the temperature coefficient of the apparent anisotropy field in $\left(\mathrm{Li}_{0.5 \times} \mathrm{Zn}_{1-x}\right)_{0.6} \mathrm{Cu}_{0.4}\left(\mathrm{Fe}_{0.95} \mathrm{Mn}_{0.05}\right)_{2+0.3 x} \mathrm{O}_{4}$.

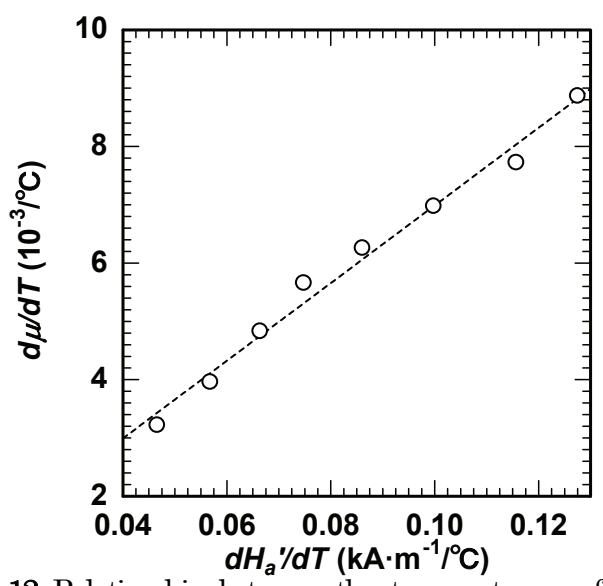

Fig. 12 Relationship between the temperature coefficient of the apparent anisotropy field $d H_{a}^{\prime} / d T$ and the static permeability $d y d d T$ in $\left(\mathrm{Li}_{0.5 .7} \mathrm{Zn}_{1-x}\right)_{0.6} \mathrm{Cu}_{0.4}\left(\mathrm{Fe}_{0.95} \mathrm{Mn}_{0.05}\right)_{2+0.3 \times} \mathrm{O}_{4}$.
Li フェライトと $\mathrm{Zn}$ フェライトとの比において $\mathrm{Li}$ フェライト が少なくなると静的透磁率は増加し，その温度依存性が強まると いう，他の組成系の高周波スピネルフェライトでも見られる現象 が確認できた。この温度依存性の強弱は, 磁気異方性に由来する 見掛けの異方性磁界の温度依存性に線形的に対応するものである ことがわかった. ただし, 他の高周波フェライトと比較すると非 常に強い水準にある感温性を示寸このフェライトの特異性は，同 等の高周波特性を有しながら比較的感温性が弱い多結晶 $\mathrm{Ni}-\mathrm{Zn}-\mathrm{Cu}$ フェライトと比較することで, $\mathrm{Li}$ フェライトの磁気異方 性定数の温度係数が大きいことに因ることを明らかにした.

今後, 感温性制御に効果があることがわかっている $\mathrm{Fe}$ の $\mathrm{Mn}$ 置 換の影響などについても考察を進めてゆく予定である.

謝辞 本研究の一部は, (財)加藤科学振興会の平成 19 年度 第 16 回研究助成金を受けて行われた. また, 本研究の遂行にあたって ご助言を賜った埼玉大学大学院理工学研究科物質科学研究部門教 授 平塚信之博士に厚く御礼申し上げる.

\section{References}

1) M. Naoe, T. Nakamura, and Y. Yamada: J. Magn. Soc. Jpn., 30, 44 (2006).

2) Y. H. Kim, S. Hashi, K. Ishiyama, K. I. Arai, and M. Inoue: IEEE Trans. Magn., 36, 3643 (2000).

3) M. Naoe, R. Takahashi, T. Omura, T. Sato, K. Yamasawa, and Y. Miura: J. Magn. Soc. Jpn., 31, 109 (2006).

4) E. Roess, I. Hanke, and E. Moser: Z. Angew. Phys., 17, 504 (1964).

5) A. Broese Van Groenou, J. A. Schulkes, and D. A. Annis: J. Appl. Phys., 38, 1133 (1967).

6) A. Globus, P. Duplex, and M. Guyot: IEEE Trans. Magn., MAG-7, 617 (1971).

7) G. C. Jain, B. K. Das, R. S. Khanduja, and S. C. Gupta: J. Mater. Sci., 11, 1335 (1976)

8) A. A. Stattar, H. M. El-Sayed, and W. R. Agami: J. Mater. Eng. Performance, 16, 573 (2007).

9) E. W. Gorter: Philips Res. Pep., 9, 295 (1954); ibid., from 321 and 403.

10) G. Ritter: Z. Phys. A, 189, 23 (1966).

11) S. Chikazumi: Physics of Ferromagnetism I (in Japanese), 5th edition, p.p. 157-159 (Syokabo, Tokyo, 1984).

12) M. Kersten: Z. Angew. Phys., 8, 382 (1956).

13) V. J. Folen: J. Appl. Phys., 31, 166S (1960).

14) A. Broese Van Groenou, J. A. Schulkes, and D. A. Annis: J. Appl. Phys., 38, 1133 (1967).

15) T. Nakamura: J. Appl. Phys., 88, 348 (2000).

16) J. L. Snoek: Physica, 14, 207 (1948).

17) K. Murakami and H. Matsuki: Temperature Sensitive Magnetic Application Engineering (in Japanese), 1st edition, p.p. 29-30 (Baifukan, Tokyo, 1993).

18) T. Nakamura, T. Miyamoto, and Y. Yamada: J. Magn. Magn. Mater., 256, 340 (2003).

19) U. Kato and M. Endo: Proc. 3rd Int. Relay Conf., 13-1 (1974).

20) K. I. Arai and N. Tsuya: Abstr. Meeting Phys. Soc. Jpn., Sectional Meeting in Autumn, 4, 74 (1969).

21) G. Tauchi, K. Kamishima, K. Kakizaki, and N. Hiratsuka: J. Magn. Soc. Jpn., 32, 58 (2008).

\section{8年4月23日受理，2008年7月14日採録}

